This PDF is a selection from a published volume from the National Bureau of Economic Research

Volume Title: The Distributional Aspects of Social Security and Social Security Reform

Volume Author/Editor: Martin Feldstein and Jeffrey B. Liebman, editors

Volume Publisher: University of Chicago Press

Volume ISBN: 0-226-24106-8

Volume URL: http://www.nber.org/books/feld02-1

Conference Date: October 21-23, 1999

Publication Date: January 2002

Title: The Economics of Bequests in Pensions and Social Security

Author: Martin S. Feldstein, Elena Ranguelova

URL: http://www.nber.org/chapters/c9755 


\title{
The Economics of Bequests in Pensions and Social Security
}

\author{
Martin Feldstein and Elena Ranguelova
}

One of the apparent advantages of Social Security and of private pensions is that they provide an annuitized form of retirement income that allows retirees to avoid "wasting" some of their lifetime accumulation in the form of unintended bequests. ${ }^{1}$ In practice, however, individuals generally choose to forgo the potential gain from full annuitization in order to have the prospect of providing a bequest with some of their lifetime accumulation.

For example, given the choice between an ordinary life annuity (for the retiree or the retiree and spouse) and a "ten-year certain" annuity that provides that benefits continue for at least ten years even if the annuitant dies, most participants in defined contribution TIAA-CREF plans select the ten-year certain annuity. ${ }^{2}$ More generally, the participants in virtually all defined contribution plans choose to bequeath the entire value of their accumulated accounts if they die before reaching retirement age instead of committing those funds to an annuity at an earlier preretirement age. ${ }^{3}$

Martin Feldstein is the George F. Baker Professor of Economics at Harvard University and president of the National Bureau of Economic Research. Elena Ranguelova was a PhD student at Harvard while this chapter was being completed; she now works for Lehman Brothers, Inc.

The authors are grateful to John Campbell, Jeffrey B. Liebman, James M. Poterba, and Andrew A. Samwick for useful discussions, and to Andrew A. Samwick for some of the analytic data used here.

1. See Brown, Mitchell, and Poterba (1999) for estimates of the utility gain that an egoistic retiree who does not place any utility value on making a bequest obtains by being able to annuitize retirement assets.

2. The Teachers Insurance and Annuity Association College Retirement Equity Fund (TIAA-CREF) is the largest private pension plan, with more than $\$ 250$ billion in assets. Among male retirees, 74 percent now choose some period of certain benefits in addition to a life annuity.

3. This paper provides an estimate of the increased value of the annuity that would be possible if individuals used their accumulated funds to purchase annuities during their preretirement years. 
Moreover, countries that have adopted investment-based Social Security programs to supplement or replace traditional pay-as-you-go (PAYGO) systems also generally provide for bequests both when individuals die before retirement and when they die during their retirement years. ${ }^{4}$ For many people, an attraction of supplementing the existing PAYGO Social Security system in the United States with an investment-based system is that it would give middle- and lower-income individuals the opportunity to accumulate wealth and make significant bequests. Recent legislative proposals for investment-based supplements to the U.S. Social Security program provide for such bequests. ${ }^{5}$ The ability to provide bequests in this way is also regarded as an advantage of using individual retirement accounts rather than a single government fund as a way of achieving an investment-based supplement to Social Security.

A mechanism for making significant bequests is attractive both to those who would receive the bequests and those who would make the bequests. The financial assets that heirs receive in this way would, if saved and spent gradually, allow them to maintain consumption in the face of substantial financial risks, including long-term unemployment, large uninsured health expenditures, or substantial property losses. In addition, financial assets give individuals the ability to quit an undesirable job and seek new work or to undertake entrepreneurial activities. ${ }^{6}$ The ability to make such bequests to children or grandchildren is appealing to those who would make them because it provides an opportunity to express generosity at the end of life (Bernheim and Severinov 1998) and because it offers the "strategic" advantage of strengthening filial loyalty (Bernheim, Shleifer, and Summers 1985).

Although it might be argued that individuals who want to make bequests could save explicitly for this purpose, it is the lack of foresight and self-discipline to accumulate for their own old age that justifies mandatory Social Security pensions. This same inability to do long-term saving can also justify helping individuals to make the bequests that they would like to make but lack the ability to achieve. ${ }^{7}$

The provision of bequests is also a matter of practical program design in a system of investment-based personal retirement accounts. Although

4. See Feldstein (1998) and World Bank (1994) for descriptions of the investment-based systems in a number of countries.

5. These include the explicit proposals that have been put forth by Senators Moynihan and Kerry, by Senators Gramm and Domenici, and by Senators Gregg and Breaux. The provision of bequests was also a feature of the two individual account proposals contained in the report of the official Social Security Advisory Council.

6. Rosen, Holtz-Eakin, and Joulfaian (1993) show that moderate-sized bequests increase significantly the probability that individuals will begin entrepreneurial activities.

7. Bequests are, of course, an uncertain way of helping children and grandchildren. An explicit form of saving to make nonrandom gifts might in principle be a useful supplement to a pension system with bequests. 
retirees could in principle be required to annuitize their accumulated assets at retirement with no provision for bequests, those individuals who die before retirement must be allowed to make bequests unless the government taxes away the entire value of their accumulated assets at death or requires that all preretirement saving be invested in the form of annuities as it accumulates. Foreign experience and the revealed preferences in private defined contribution plans in the United States imply that neither of those would be popular options.

Previous academic analyses of investment-based Social Security reforms have ignored the possibility of bequests, implicitly assuming that all saving would be invested in annuities both during working years and after retirement (see, for example, Feldstein and Samwick 1997, 1998a, b; Kotlikoff 1996, 1998). In contrast, the present paper examines a variety of possible options for bequests before retirement and during the retirement years. Although our calculations use the individual employee as the unit of analysis, the level of projected PAYGO benefits to which we compare the investment-based annuities corresponds to the Social Security actuaries' projections for the benefits of retirees, spouses, survivors, and the disabled. ${ }^{8}$ The bequests that we study here are therefore supplementary to these additional benefits that are specified in current law.

We examine three types of issues about such bequests. First, we ask how expensive such bequests would be in terms of the saving rate necessary to support such bequests without reducing the associated annuities. Alternatively, we ask how much of an annuity reduction different bequest rules would require if the saving rate used to fund the investment-based pensions was not raised when bequests were introduced. Next, we examine the probability distribution of bequests by size and by timing under different bequest options. Finally, we consider the macroeconomic consequences of bequests on capital accumulation.

\subsection{Personal Retirement Accounts and Preretirement Bequests}

In an investment-based system, individuals accumulate a fraction of each year's wages in personal retirement accounts (PRAs) during working years and receive annuities during retirement. The deposits to these accounts may be financed by the individuals themselves, by their employers, or by the government. The deposits may be set at a level that permits the resulting annuities to fully replace the PAYGO system of benefits or at a level that only supplements a PAYGO system. The issues of who funds the accounts and of whether the accounts are intended to replace the existing PAYGO system or to supplement the existing system are not directly rele-

8. About one-third of the total cost of benefits is for the additional benefits for spouses, survivors, dependents, and the disabled. 
vant to our analysis. ${ }^{9}$ The structure of the calculations makes it clear that the size of the annuities and of the bequests is proportionate to the saving rate. Although we analyze a level of saving that could fully replace the existing PAYGO system in the long run, readers can consider the effect of smaller investment-based programs by a proportionate reduction in all of our dollar amounts.

In a system with no preretirement bequests, the individual is implicitly required to buy a retirement annuity with each year's PRA deposit. The rate of return on the preretirement saving of those who survive in any given year is therefore the sum of the ordinary market return on the assets in the account plus the increased value that results from receiving a share of the assets of those who died during the year.

More specifically, consider a cohort of individuals who enter the labor force at age twenty-one. Let $N_{s}$ be the number of individuals of the cohort who are alive and working at age $s$, let $w_{s}$ be the annual wage of the representative individual in that cohort in year $s$, let $\alpha$ be the fraction of wages contributed each year to the PRAs, ${ }^{10}$ and let $R_{s}$ be the investment return in that year. If bequests are not permitted, the funds that are owned by those who die at age $s$ are automatically reinvested in the accounts of those who remain alive, as they would be in an actuarially fair annuity. During the preretirement period, those who live to the end of their sth year will have accumulated (as a cohort) an amount

$$
M_{s}=\left(1+R_{s-1}\right) M_{s-1}+\alpha w_{s} N_{s},
$$

where $M_{s}$ is the aggregate PRA balance for the cohort as a whole. A representative member of the cohort who survives to age $s$ will therefore have accumulated

$$
A_{s}=\left(1+R_{s-1}\right) A_{s-1}+\alpha w_{s}+\left(1+R_{s-1}\right) \frac{\left(N_{s}-N_{s-1}\right) A_{s-1}}{N_{s}},
$$

where the term $\left(\left[N_{s}-N_{s-1}\right] A_{s-1}\right) / N_{s}$ indicates the amount transferred to each survivor's account in year $s-1$ from those who died during that year.

Permitting bequests of the accumulated account balances during the preretirement years changes this accumulation by eliminating the increment in equation (2) that comes from the accounts of those who died dur-

9. Feldstein and Samwick (1997, 1998b) analyze plans based on employee-employer contributions that would eventually replace the existing tax-financed system completely. Feldstein and Samwick (1998a, 1999) describe a plan to use government deposits in individual accounts to supplement the benefits that could be financed with the existing level of Social Security payroll taxes. Feldstein, Ranguelova, and Samwick (1999) analyze both types of plan in a stochastic environment.

10. Saving in PRAs is based on wages up to the maximum earnings taxed under Social Security. This maximum was \$68,400 in 1998 . 
ing the year. The value of the assets of an individual who survives to age $t$ (and therefore the magnitude of that individual's bequest if he or she dies in that year) evolves according to

$$
A_{s}=\left(1+R_{s-1}\right) A_{s-1}+\alpha w_{s} .
$$

To assess the magnitude of the potential bequests and the effect of bequests on the amount accumulated at age sixty-six, we use the cohort of individuals who are twenty-one years old in the year 1998 and the agespecific mortality rates for this cohort as projected by the Social Security actuaries in the Statistical Supplement to the Social Security Bulletin. We look at a representative individual in this cohort who has mean agespecific earnings in each year, again using the projections of the Social Security actuaries.

\subsection{A Model of Uncertain Investment Returns}

Our analysis assumes that the PRA balances are invested in a portfolio consisting of 60 percent stocks and 40 percent corporate bonds. The accumulation of assets in the PRAs and the annuities and bequests at each age reflect the uncertain returns on these assets.

To analyze this uncertainty, we assume that the PRA portfolio is continually rebalanced to maintain 60 percent equities and 40 percent debt. ${ }^{11} \mathrm{We}$ use the Standard \& Poor's 500 index and a Salomon Brothers corporate bond index as proxies for the stock and bond investments. Both indexes are assumed to follow a geometric random walk with drift. This implies that the $\log$ returns for each type of asset are serially independent and identically distributed with given mean and variance. Thus, if $p_{e s}$ and $p_{b s}$ are the log levels of the equity and bond indexes at time $s$, we assume

$$
p_{e s}=p_{e(s-1)}+\mu_{e}+u_{e s}
$$

and

$$
p_{b s}=p_{b(s-1)}+\mu_{b}+u_{b s}
$$

where $\mu_{e}$ and $\mu_{b}$ are the mean drift per period in the logarithmic value of equities and bonds, while $u_{e} \sim$ independently and identically distributed (i.i.d.) $N\left(0, \sigma_{e}^{2}\right)$ and $u_{b} \sim$ i.i.d. $N\left(0, \sigma_{b}^{2}\right)$. The covariance between the stock and bond returns is $\sigma_{e b}$.

With a continuously compounded $60-40$ equity-debt portfolio, the log

11. This ratio is selected to correspond approximately to the debt-to-equity ratio of U.S. corporations so that the rate of return on capital at the corporate level can correspond to the return to these portfolio investments without considerations of the relative yields on debt and equity. The $60-40$ ratio is also a common ratio used by corporate pensions. 
level of the overall portfolio would satisfy the following random walk if there were no additions or payouts:

$$
p_{s}=p_{s-1}+\mu+u_{s}
$$

with $u \sim$ i.i.d. $N\left(0, \sigma^{2}\right)$. To derive the values of $\mu$ and $\sigma^{2}$ we use the lognormal property of the returns.

More specifically, if $\mu_{i}^{*}$ is the mean return on asset $i$ in level form, the mean return on the 60-40 portfolio is the weighted average $\mu^{*}=0.6 \mu_{e}^{*}+$ $0.4 \mu_{b}^{*}$. Because we assume the $\log$ returns to be normally distributed, $\mu_{i}^{*}=\mu_{i}+0.5 \sigma_{i}^{2}$. This implies that

$$
\mu+0.5 \sigma^{2}=0.6\left(\mu_{e}+0.5 \sigma_{e}^{2}\right)+0.4\left(\mu_{b}+0.5 \sigma_{b}^{2}\right),
$$

where

$$
\sigma^{2}=0.36 \sigma_{e}^{2}+0.16 \sigma_{b}^{2}+0.48 \sigma_{e b} .
$$

From these two equations and the measured mean and variance of the log returns on stocks and bonds, we can derive the log return on the portfolio and the variance of that return.

The Center for Research in Security Prices (CRSP) data for the postwar period from 1946 through 1995 imply that for stocks and bonds the mean log real rates of return were 7.0 percent and 3.3 percent. ${ }^{12}$ The corresponding standard deviations are 16.6 percent for stocks and 10.4 percent for bonds. The covariance of the stock and bond log returns is $\sigma_{e b}=0.0081$. Taken together, these parameters imply an average log real rate of return on the 60-40 portfolio of 5.9 percent with a standard deviation of 12.5 percent.

In the analysis that follows, we reduce the mean log return from 5.9 percent to 5.5 percent to reflect potential administrative costs. ${ }^{13}$

Although the equation for $p_{s}$ describes the way that the logarithmic value of the PRA account would evolve during the accumulation years if there were no external additions, the actual individual PRAs would be augmented annually by a fraction $\alpha$ of the individual's wage and, when there are no preretirement bequests, by the distributed share of the PRA balances of those members of the cohort who die during the year. These are shown in equations (2) and (3) above. Since those equations are stated in level rather than logarithmic form, the value of $1+R_{s}=\exp \left(r_{s}\right)$ where $r_{s}$ is the logarithmic rate of return in period $s$ implied by $r_{s}=p_{s}-p_{s-1}=$ $\mu+u_{s}$.

12. The bond rate of return is based on the Salomon Brothers' AAA bond returns, adjusted to a more typical corporate bond yield by adding 2 percentage points.

13. This estimate of the administrative cost may be compared with the cost of about 0.2 percent charged now in indexed equity funds by mutual fund companies like Vanguard and Fidelity. Bond funds generally have lower administrative charges. 
We use equation (3) to simulate 10,000 evolutions of the PRA values for each year from age 21 through 100, taking into account the mortality probabilities and the stochastic distribution of returns. Our stochastic simulations recognize the uncertainty of the future mean return as well as the annual variations in returns around that future mean. For each of the 10,000 simulations, we begin by drawing a mean rate of return from a distribution with a mean of 0.055 and a standard deviation of 0.0177 , the standard error or the mean estimate based on our fifty-year sample of observations. We then generate an eighty-year series of returns that have this mean and a standard deviation of 0.125 .

We assume that individuals save 6 percent of their wages each year in PRA accounts and that the PAYGO tax declines from the initial 12.4 percent to zero. For comparison, the Social Security actuaries project that the current PAYGO tax rate of 12.4 percent will have to rise to more than 18 percent in a purely tax-financed PAYGO system in order to provide the benefits that are promised in the Social Security law. In contrast, we show in this paper that, with no bequests and a saving rate of 6 percent, the median annuity at age sixty-seven is 2.05 times the future Social Security benefits promised in current law (which we call the "benchmark benefits") and that there is a 90 percent probability that the PRA annuity at age sixty-seven will equal or exceed 76 percent of the benchmark benefit. ${ }^{14}$ Since the benchmark PAYGO benefit replaces approximately 40 percent of the preretirement wage, the median annuity based on a 6 percent replacement rate would correspond to a replacement rate of 81 percent. The mean annuity exceeds the median and corresponds to 2.98 times the benchmark benefits.

\subsection{The Distribution of Preretirement Bequests}

We now study the annuity financed by a 6 percent saving rate to see the effects of mortality risk and investment uncertainty on the distribution of bequests. Table 9.1 shows the implied distribution of preretirement bequests of different sizes for individuals who die at different ages between twenty-five and sixty-seven. These bequests are all based on the potential experience of a representative individual who earns the mean wage ${ }^{15}$ and who makes annual saving deposits of 6 percent of that wage to a PRA. The distribution of bequest values reflects the variation in rates of return on the assets in the PRAs. Column (1) shows the annual age-specific

14. For a more complete analysis of these risk issues, see Feldstein and Ranguelova (1998).

15. The mean wage is the mean of the wage distribution subject to the ceiling on the taxable earnings for Social Security $(\$ 68,400$ in 1998) and adjusted for multiple excess wages. The multiple excess wages adjustment accounts for the fact that some individuals who receive wages from more than one employer may earn less than the taxable ceiling at each job but that their total earnings may exceed that ceiling. 


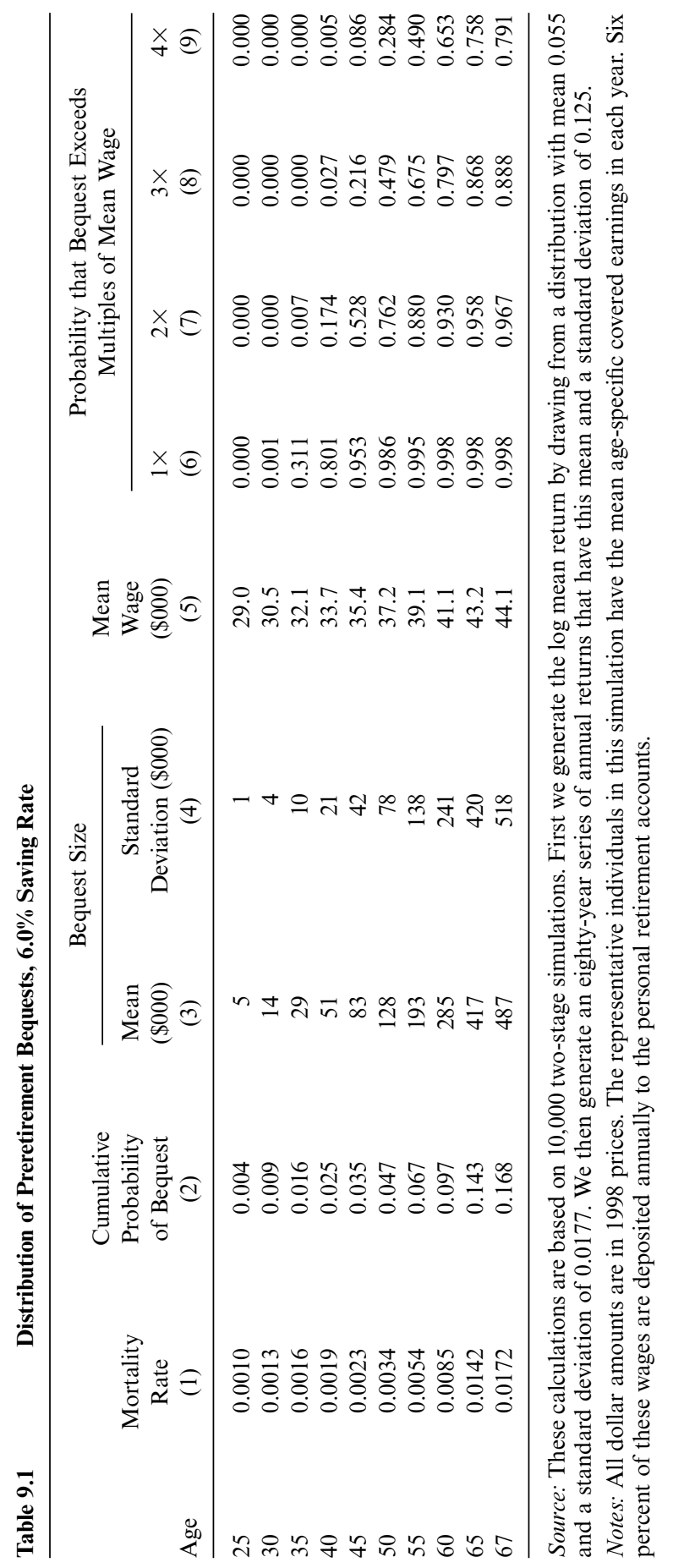


mortality rates, the probabilities that an individual of that age will die and leave a bequest. The cumulative probability of leaving a bequest (i.e., the probability of dying by that age conditional on being alive at age twentyone) is shown in column (2).

The mean and standard deviation of those bequests, in thousands of 1998 dollars, is shown in columns (3) and (4). For comparison, the corresponding mean wage projected for that year is shown in column (5). ${ }^{16}$ The simulation of 10,000 forecasts is used to calculate the probabilities that the bequest will exceed various multiples of the future mean wage; these probabilities are shown in columns (6) through (9).

The mean bequests grow rapidly with age, from just $\$ 5,000$ for those who die at age twenty-five to $\$ 128,000$ at age fifty, and more than $\$ 400,000$ for those who die just before retirement. Even by age thirty-five, the mean bequest of an individual who has had average earnings all his life would be nearly as large as the average earnings in that year. By age fifty, the mean bequest is more than three times mean earnings. Recall that this is with a 6 percent saving rate. If the saving rate were limited to 2 percent of earnings, as it might be in a system that combines PAYGO and investmentbased components, these means and standard deviations would be reduced by a factor of three.

The increasing relative variance of the bequest size (seen by comparing columns [4] and [3]) reflects the fact that the annual returns follow a random walk, causing the variance of the return to grow with time. The probability distributions described in columns (6) through (9) show that those who die in middle age are increasingly likely to leave bequests that are a significant multiple of the average wage at the time of their death. Thus, among fifty-year-olds who die, virtually all bequests exceed the average wage, 76 percent of bequests exceed twice the average, and 48 percent exceed three times the average wage.

In considering these values, it should be recalled that the cost of providing these preretirement bequests while maintaining the 6 percent PRA saving rate is to reduce the funds available to finance annuities among the vast majority of individuals who do not die before reaching retirement age. The payment of preretirement bequests reduces the mean accumulation of assets at age sixty-six by 14 percent, causing the annuities to decline by the same percentage. Table 9.2 shows the effect of providing preretirement bequests on the distribution of the variable annuity payments. We report the variable annuity payments as a fraction of the "benchmark benefits" the benefits promised to each cohort under the Social Security law. ${ }^{17}$ The first three columns show the cumulative probability distributions of

16. This is also the mean of the truncated distribution, with all wages at or above the ceiling truncated as if they are at the celing and adjusted for multiple excess wages.

17. See section 9.4 for a description of the variable annuities. 


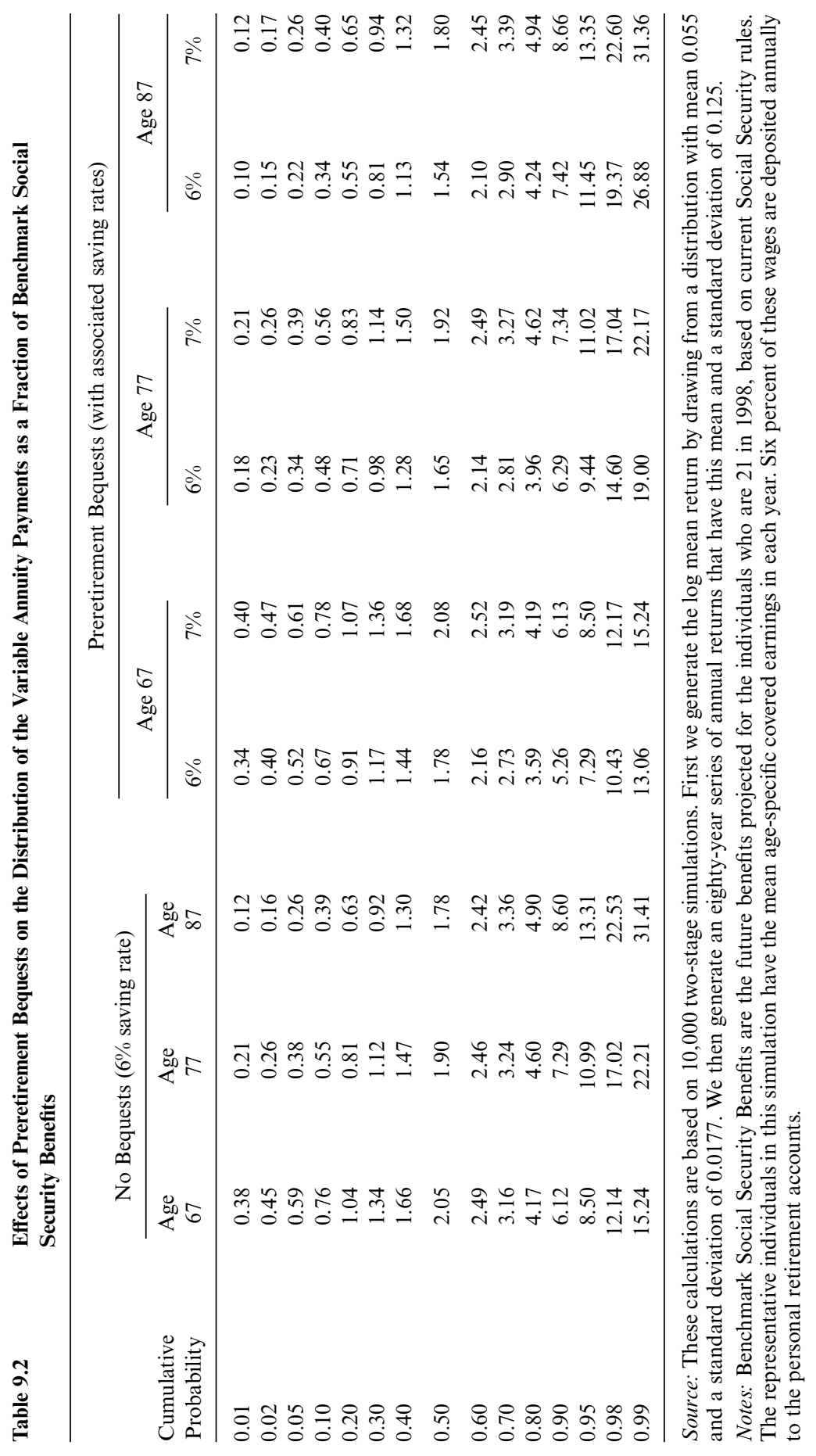


annuity payments relative to benchmark benefits for retirees at ages sixtyseven, seventy-seven, and eighty-seven with no preretirement bequest and a 6 percent saving rate. The next six columns show the same cumulative distributions, but for the case in which individuals can bequeath their accounts if they die before age sixty-seven. For this case, we consider PRA saving rates of 6 percent and 7 percent.

The results indicate that permitting preretirement bequests does not significantly increase the risk to retirees and that the increased risk can be fully offset by raising the PRA saving rate from 6 percent to 7 percent. With that increase in the saving rate, the risk distribution of annuity payments with preretirement bequests is essentially the same as the distribution with no bequests and a 6 percent saving rate. The median benefit with the 7 percent saving rate and preretirement bequests is 2.08 times the benchmark benefit level (column [6]), virtually unchanged from the 2.05 times the benchmark value with the 6 percent saving rate and no bequests (column [2]). The corresponding values at the 10th percentile of the distribution are 0.78 times the benchmark and 0.76 times the benchmark. The similarity continues at the higher age levels shown in table 9.2.

The logic of the calculation is such that the same 17 percent proportional increase in the saving rate would be sufficient for any initial saving rate. For example, a PRA annuity that is intended to supplement rather than replace the tax-financed retirement Social Security benefits would produce essentially the same distribution of annuities with either a 2.00 percent saving rate and no bequests or a 2.33 percent saving rate and preretirement bequests.

\subsection{Postretirement Bequests}

The magnitude of potential bequests is increased substantially if retirees can bequeath some part of their postretirement income as well as their preretirement accumulation. We consider first how a variable annuity system would work and then examine a variety of alternative bequest options, assessing the cost in terms of reduced annuities or increased preretirement savings needed to produce those bequests. We begin with a life annuity for the retiree alone and then extend our analysis in section 9.5 to a double life annuity for the retiree and a spouse.

Our analysis assumes that the postretirement annuity is financed with the same stock-bond mix that the individuals had during the preretirement years. When there is no postretirement bequest, we assume that the individual receives variable annuity payments that adjust according to the changes in the value of the PRA account balance caused by changes in market rates of return. More specifically, in a standard variable annuity contract, the "baseline" annuity benefit that would be paid at age sixtyseven (on an annuity purchased at age sixty-six) reflects the PRA assets at 
the beginning of the individual's sixty-sixth year, the expected mortality rates at all future ages, and the assumption that the future return will be equal to the expected portfolio rate of return (5.5 percent in the current context). Each year the actual size of the variable annuity payment is increased or decreased from the initial value in proportion to the change in the market value of the PRA assets relative to the market value that would have prevailed if the expected 5.5 percent return had actually occurred.

More explicitly, let $A_{66}$ be the value of the assets that the individual has accumulated at the beginning of the sixty-sixth year, let $R$ be the expected real rate of return on the portfolio of assets used to finance the retirement annuity, and let $p_{s \mid 66}$ be the probability of reaching age $s$ conditional on being alive at age sixty-six. The actuarial present value (APV) at age sixtysix of a fixed real annuity of $\$ 1$ for life beginning at age sixty-six is then

$$
\mathrm{APV}=\sum_{s=67}^{s=100} p_{s \mid 66}(1+R)^{-(s-66)},
$$

where we assume that all individuals alive at age 99 die at the end of the 100 th year. Since the PRA account has assets equal to $A_{66}$ when the annuity is established, the annual annuity that the individual would receive in the sixty-seventh year is $a_{67}=A_{66} / \mathrm{APV}$ if the expected return of $R$ is actually realized in the sixty-sixth year. In practice, of course, the actual rate of return varies from year to year. The annuity payments are adjusted in proportion to the annual changes in the asset value in such a way that the accumulated fund of the individuals with survival probabilities $p_{s \mid 66}$ is exhausted over the thirty-four-year potential retirement period. If $R_{s}$ is the actual rate of increase of the asset value during year $s$, the value of the annuity paid in that year is $a_{67}=\left(A_{66} / \mathrm{APV}\right)\left(\left[1+R_{66}\right] /[1+R]\right)$. Similarly, the annuity at age sixty-eight reflects the changes in the market value of the assets during the sixty-sixth and sixty-seventh years: $a_{68}=a_{67}\left(\left[1+R_{67}\right] /[1+R]\right)=$ $\left(A_{66} / \mathrm{APV}\right)\left(\left[1+R_{67}\right] /[1+R]\right)\left(\left[1+R_{66}\right] /[1+R]\right)$.

These annuity payments leave no room for postretirement bequests in the sense that, for the birth cohort as a whole, the annuity payments between ages 67 and 100 just exhaust the aggregate value of the assets that had been accumulated at age sixty-six. It is possible, however, to reduce each annuity payment by some factor $k$ and provide for a bequest at the time of the retiree's death. The value of $k$ will depend on the particular bequest rule. We now consider two of the many possible types of possible bequest rules: (a) rules that combine actuarial life annuities and $N$-year certain payouts, and (b) a residual balance bequest rule that provides a lifetime annuity but also a bequest equal to the original accumulated PRA balance at the time of retirement $\left(A_{66}\right)$ supplemented by the increases in the nominal account value resulting from investment returns until the time of death and reduced by the sum of the actual annuities paid to the retiree. Our use of a variable annuity (i.e., one in which the annuitant takes the 
risks associated with investing in a stock-bond portfolio) precludes bequest rules that promise a fixed dollar payment at death. ${ }^{18}$

Table 9.3 compares the costs and benefits of the different postretirement bequest rules. All of the options are assumed to include full preretirement bequests. The basic PRA saving rate in these simulations is 6 percent of wages.

The first row corresponds to the case (studied in section 9.3) in which there is a preretirement bequest but no postretirement bequest. With the 6 percent saving rate, the mean value of the annuity at age sixty-seven in 10,000 simulations is equal to 2.57 times the benchmark Social Security benefit in current law; this is shown in column (2). The corresponding median annuity, shown in the fifth column of table 9.2, is 1.78 times the benchmark benefit. The annuity reduction factor (column [1]) is the constant proportionality factor, $k$, by which the specified postretirement bequest reduces all annuity benefits relative to the benefits that would be paid with the preretirement bequest but no postretirement bequest. By definition, $k=1$ for the "No Bequest" option of the first row. The "Required PRA Saving Rate" shown in column (3) is the saving rate required to have the same mean annuities at each retirement age as the option with no postretirement bequest based on a 6 percent saving rate (i.e., 6.0/k).

\subsubsection{Ten-Year and Twenty-Year Certain Annuities}

In private pension plans, a popular alternative to a pure life annuity is an option that provides for a minimum number of years of annuity payments even if the retiree dies during those years. Two common forms are the "ten-year certain life annuity" and the "twenty-year certain life annuity." If the retiree dies after this specified period, there is no bequest.

The proportional reduction in the regular life annuity that is required to permit a ten-year certain payment is calculated by equating the actuarial present value of the regular life annuity $\left(\sum_{s=67 \text { to } 100} a_{s} p_{s \mid 66}[1+R]^{-(s-66)}\right)$ to the sum of a fixed ten-year reduced annuity $\left(\sum_{s=67 \text { to } 76} k a_{s}[1+R]^{-(s-66)}\right)$ and the actuarial present value of the similarly reduced life annuity beginning eleven years after retirement $\left(\sum_{s=77 \text { to } 100} k a_{s} p_{s \mid 66}[1+R]^{-(s-66)}\right)$, where $1+R=$ $E\left(e^{r(s)}\right)$ is the expected value of the gross return. The value of $k$ calculated in this way implies that the preretirement saving rate that would be required to maintain the initial annuity distribution is simply the basic saving rate divided by the value of $k$ because that raises the PRA assets at the time of retirement by the factor $1 / k$.

The results for ten-year and twenty-year certain annuities are shown in the second and third rows of table 9.3. A ten-year certain payment reduces the available annuity by only 6 percent (i.e., by the factor $k=0.94$ in

18. In practice it would, of course, be possible to have a portion of the funds in a fixed annuity, so that a fixed dollar payment at death could be promised. 


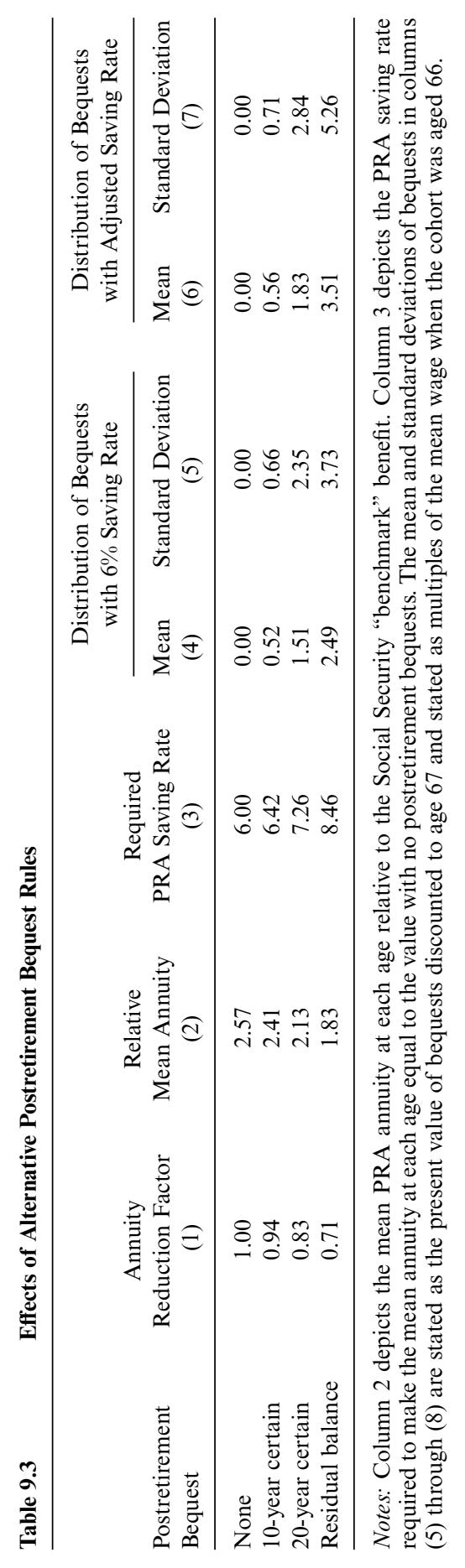


column [1]). The ability of a 6 percent reduction in the annuity payment to compensate for the fact that the annuity will be paid for at least ten years even if the retiree dies before age seventy-seven reflects the relatively low mortality probability during those years. With the basic 6 percent saving rate, the mean annuity at age sixty-seven is still 2.41 times the benchmark Social Security benefit. Achieving the same mean annuity with the ten-year certain payment as with no postretirement bequest requires increasing the 6 percent saving rate by a factor of $1 / k=1.064$ to a saving rate of 6.42 percent (shown in column (3).

The postretirement bequests are separate from the preretirement bequests and, for the cohort as a whole, are in addition to them. For any individual, the mean expected bequest is $p$ (death before age sixty-seven) * (mean preretirement bequest $)+(1-p$ [death before age sixty-seven] $) *$ (mean postretirement bequest.)

Columns (4) and (5) show the mean and standard deviation of the postretirement bequests that would be available with the basic 6 percent saving rate. These bequest values are the present values as of age sixty-seven (discounting at the expected return on the PRA balances) and are reported as a multiple of the projected mean wage in the year that the cohort reached age sixty-seven ( $\$ 44,087$ in 1998 dollars). The value of 0.52 in column (4) of the second row implies that the mean of the postretirement bequests in the 10,000 simulations has a present value as of age sixty-seven of $\$ 22,925$. Associated with this mean present value of bequests is a standard deviation shown in column (5). In interpreting this standard deviation, it should be noted that the distribution is lognormal and therefore not symmetric.

With the adjusted saving rate that is needed to maintain the same distribution of annuity payments that would prevail with no postretirement bequests - a saving rate of 6.42 percent - the value of the bequests rises by the same proportional amount. The mean bequest shown in column (6) is 0.56 times the mean wage in the year that the cohort reaches age sixtyseven.

A twenty-year certain rule means that the annuity payments continue after death until at least the time when the retiree would have been eightyseven years old even if he dies before then. The extra ten years of guaranteed payments at a time when the mortality rate is increasing rapidly require a further reduction in benefits of 11 percent of the standard benefit, from 94 percent of the standard annuity with the ten-year certain rule to 83 percent with the twenty-year certain rule. However, even with this reduction, the 6 percent PRA saving rate implies a mean annuity at age sixty-seven that is still 2.13 times the benchmark Social Security benefit. To offset this decrease and achieve the same annuity distribution that would occur with no postretirement bequest requires increasing the 6 percent saving rate to 7.26 percent.

Columns (4) and (5) show the mean and standard deviation of the pres- 
ent value of postretirement bequests that would be available with the basic 6 percent saving rate, reported as a multiple of the mean wage in the year that the cohort reached age sixty-seven. The mean present value bequest as of age sixty-seven with the 6 percent saving rate is $\$ 66,571$; this rises to $\$ 80,679$ if the saving rate is adjusted to 7.26 percent.

\subsubsection{Residual Balance Annuities}

An alternative type of bequest rule would give heirs the actuarial value of the remaining lifetime annuity payments at the time of the retiree's death. This is equivalent to the original account value at the time of retirement $\left(A_{66}\right)$ reduced by the sum of the annuities actually paid and supplemented by the increases (or decreases) in the nominal account values resulting from the investment returns. More explicitly, if the retiree dies at age $s$ after receiving the annuity payment $k a_{s}$ the bequest would evolve according to $A_{s}=\left(1+R_{s-1}\right) A_{s-1}-k a_{s}$. We refer to this as the residual balance bequest and show the main effects in the fourth row of table 9.3.

The required value of $k$ can be calculated by equating the actuarial present value of the regular life annuity $\left(\sum a_{s} p_{s \mid 66}[1+R]^{-(s-66)}\right)$ to the sum of the actuarial present value of the reduced annuity $\left(\sum k a_{s} p_{s \mid 66}[1+R]^{-(s-66)}\right)$ and the actuarial present value of the bequests $\left(\sum\left[p_{(s+1) \mid 66}-p_{s \mid 66}\right] A_{s}[1+R]^{-(s-66)}\right)$ where $p_{(s+1) \mid 66}-p_{s \mid 66}$ is the probability of dying at age $s$ and $1+R=E\left(e^{r(s)}\right)$ is the expected return on the PRA balance. We find that $k=0.71$, a 29 percent reduction in the potential annuity levels relative to providing only preretirement bequests.

Even with this reduction, the PRA program with a 6 percent saving rate would provide a mean annuity that is 1.83 times the benchmark Social Security benefit (column [2]). To maintain the "no postretirement bequest" probability distribution of annuity income while giving the "residual balance" bequest requires raising the saving rate from 6.0 percent to 8.5 percent (column [3]).

Turning from the annuities to the bequests, with the 6 percent saving rate the present value of bequests as of age sixty-seven is 2.49 times the mean wage in the year that the cohort reaches age sixty-seven, or $\$ 109,777$ in 1998 prices. With the saving rate raised to 8.5 percent to maintain the original distribution of retirement annuities, the mean present value of the bequests rises to $\$ 154,745$.

\subsection{Bequests to Spouses and Double Life Annuities}

Bequests to spouses are different from intergenerational transfers. Social Security provides additional benefits to surviving spouses whose own benefits are relatively low, and private pension plans in the United States are required to continue annuity payments to surviving spouses unless a spouse specifically relinquishes his or her right to a benefit. 
There are a variety of possible arrangements for providing annuity benefits to a surviving spouse. ${ }^{19}$ The simplest of these is a double life annuity. This provides that the variable annuity continues to be generated in the same way until both the retiree and the retiree's spouse have died. The cost of providing such a double life annuity depends on the sex of the primary beneficiary (the "retiree") and the difference in age between the retiree and the spouse. For our calculations, we assume a male retiree who is two years older than his wife.

With this assumption, the probability that the spouse is alive at the time of the retiree's death decreases from 0.89 if the retiree dies at age sixtyseven to 0.75 if the retiree dies at seventy-seven and 0.51 if the retiree dies at eighty-seven. Our simulations imply that replacing a single life annuity with a double life annuity reduces the annuity that can be financed with our 60-40 stock-bond investment mix by 20 percent. Alternatively, maintaining the same annual payments if the single life annuity is replaced with a double life annuity requires raising the saving rate by 25 percent, increasing, for example, from 6.0 percent to 7.5 percent.

The double life annuity can also be extended to permit bequests to other heirs after the retiree and the retiree's spouse have both died. Using the residual balance method of calculating bequests means permitting other heirs to receive the actuarial value of the remaining account balance. This is equivalent to reducing the original account value at the time of retirement $\left(A_{66}\right)$ by the sum of the annuities paid to the retiree and spouse and supplementing it with the increases in the account values resulting from the investment returns. If the "second to die" dies when the retiree would have been age $s$, the bequest would be $A_{s}$, which evolves from $A_{66}$ according to $A_{s}=\left(1+R_{s-1}\right) A_{s-1}-k a_{s}$. Table 9.4 shows the probability of bequest to nonspousal heirs, the mean bequest, and the standard deviations of the bequests at each age as well as the overall mean and standard deviation of the bequests. These bequests are shown as multiples of the mean earnings of employees in each year. The projected mean earnings (in 1998 dollars) in each year are shown for comparison. The analysis for bequests in all years (shown in the last row of the table) converts the bequests into multiples of mean covered earnings in the year that the bequest is received.

The probability of a bequest shown in column (1) includes preretirement as well as postretirement bequests. In both situations, the other heirs receive bequests only if both the husband and wife have died.

19. Recall that our basic analyses (e.g., Feldstein and Samwick 1998a; Feldstein and Ranguelova 1998) assume that benefits will be provided, as specified in current law, to spouses, survivors, and the disabled as well as to retirees. The bequests that we study in this paper would be supplementary to these additional benefits already provided in current law. Note that, with a PRA saving rate of 6 percent, the benefits that we calculate are not of the amount that must be set aside to pay the disability and survivor benefits called for in current law. Operationally, a fraction of the 6 percent PRA saving could be set aside to purchase survivor and disability insurance while still financing the retirement benefits cited in this paper. 
The probability that an heir other than a spouse receives a benefit in any year is low until the primary retiree is quite old, because until then the probability that at least one spouse is alive is quite high. With the 6 percent saving rate assumed in these calculations, the mean bequests when they occur are quite substantial, rising from $\$ 126,000$ (3.4 times average individual annual earnings) at age fifty to $\$ 324,000$ (7.2 times average individual annual earnings) when the second member of the couple dies at the time that the primary annuitant would have been seventy years old. This amount is six times the annual individual earnings in the year of bequest. The final row of table 9.4 shows that the mean bequest is 5.1 times the average covered earnings in the year that the bequest is made.

The bequests described in table 9.4 assume a couple with only a single earner, an increasingly rare situation in the American economy. When both members of a couple work, a double life annuity with residual bequests offers more attractive prospects to other heirs. We analyze in table 9.5 the situation for a two-earner couple, both of whom have double life annuities. In this analysis, both members of the couple receive a PRA annuity while they are alive. When the first member of the couple dies, the remaining member of the couple receives both annuity payments. At the death of the remaining member, the other heirs receive the actuarial value of the remaining balances in both annuities.

The specific distribution of such residual balance bequests depends on the ages of the couple and on the amounts that each earns. As an example, we consider a couple in which both members earn the average wage and in which the wife is two years younger than her husband. We assume that the preretirement bequest that is paid to a surviving spouse is consumed

Table 9.4

Postretirement Bequests to Nonspousal Heirs with a Double Life Annuity

\begin{tabular}{lcccc}
\hline Age & $\begin{array}{c}\text { Probability } \\
\text { of Bequest to } \\
\text { Nonspousal Heirs } \\
(1)\end{array}$ & $\begin{array}{c}\text { Mean } \\
\text { Bequest } \\
(2)\end{array}$ & $\begin{array}{c}\text { Standard } \\
\text { Deviation } \\
\text { of Bequest } \\
(3)\end{array}$ & $\begin{array}{c}\text { Mean } \\
\text { Earnings } \\
(\$ 000) \\
(4)\end{array}$ \\
\hline 30 & 0.000008 & 0.5 & 0.1 & 31 \\
40 & 0.000032 & 1.5 & 0.6 & 34 \\
50 & 0.000097 & 3.4 & 2.1 & 37 \\
60 & 0.000550 & 6.9 & 5.8 & 41 \\
70 & 0.004024 & 7.2 & 8.6 & 45 \\
80 & 0.020680 & 6.3 & 10.1 & 50 \\
90 & 0.075238 & 4.5 & 9.8 & 55 \\
All & & 5.1 & 10.0 & 42 \\
\hline
\end{tabular}

Notes: The PRA account earns a mean return of 5.5 percent with a standard deviation of 12.5 percent; see text for more details. The employee in these calculations is a male with a spouse who is two years younger. Bequests are stated as multiples of the mean earnings in the year of the bequest. Mean earnings, shown in column (5), are in constant 1998 dollars. 
Postretirement Bequests to Nonspousal Heirs: Two-Earner Couples with a Double Life Annuity

\begin{tabular}{lcccc}
\hline & $\begin{array}{c}\text { Probability } \\
\text { of Bequest to } \\
\text { Nonspousal Heirs } \\
(1)\end{array}$ & $\begin{array}{c}\text { Mean } \\
\text { Bequest } \\
(2)\end{array}$ & $\begin{array}{c}\text { Standard } \\
\text { Deviation } \\
\text { of Bequest } \\
(3)\end{array}$ & $\begin{array}{c}\text { Mean } \\
\text { Earnings } \\
(\$ 000) \\
(4)\end{array}$ \\
\hline 30 & 0.000015 & 0.5 & 0.1 & 31 \\
40 & 0.000065 & 1.6 & 0.7 & 34 \\
50 & 0.000218 & 3.6 & 2.2 & 37 \\
60 & 0.001129 & 7.2 & 6.1 & 41 \\
70 & 0.007612 & 9.6 & 11.4 & 45 \\
80 & 0.036794 & 10.5 & 16.7 & 50 \\
90 & 0.131211 & 7.7 & 16.6 & 55 \\
All & & 7.1 & 15.5 & 42 \\
\hline
\end{tabular}

Notes: The PRA account earns a mean return of 5.5 percent with a standard deviation of 12.5 percent; see text for more details. Husband and wife in these calculations both earn the mean age-specific covered earnings in each year. Bequests are stated as multiples of the mean earnings in the year of the bequest. Mean earnings, shown in column (4), are in constant 1998 dollars. The age refers to the age of the husband in the year of the bequest.

during his or her lifetime. Although we understand that additional amounts may be bequeathed, for the purpose of this analysis we count as a bequest to other heirs only the amounts that come directly from PRA accounts or annuities and not funds that were accumulated by the decedent from previous bequests received or in other ways. Table 9.5 shows, as a function of the age that the husband is or would have been, the probability of a bequest to nonspousal heirs, the mean and standard deviation of those bequests, and the average earnings in that year.

The probability of a residual balance bequest to other heirs during the preretirement years is higher in a two-earner couple than in a single-earner couple because a wife who is the second to die has a PRA balance to bequeath. In a single-earner couple, the other heirs receive a preretirement PRA bequest only if the husband is the second to die. ${ }^{20}$ Similarly, a widow who dies in the postretirement years and who has had no labor earnings of her own has no PRA account if her husband died before age sixtyseven. She therefore leaves no PRA bequest. In contrast, a widow who had her own earnings history can leave her annuity to her nonspousal heirs even if her husband died before she died.

The expected value of the bequests is also higher in the two-earner case, because on the death of the second spouse the heirs can receive the residual balance of two accounts per couple if both spouses die after age sixty-six.

20. Recall the distinction introduced in the previous paragraph between PRA bequests and other bequests. 


\subsection{Macroeconomic Consequences of Bequests}

An investment-based Social Security system in which the PRA deposits represent incremental saving also raises the national saving rate. An examination of the potential magnitude of the increased capital accumulation is presented by Feldstein and Samwick (1998a), who estimate the evolution of PRA assets in an economy in which population and wage earnings grow between the years 1995 and 2070 according to the projections of the Social Security actuaries. The Feldstein-Samwick analysis assumes that 2 percent of the covered wages of each employee are deposited in PRAs each year, that these assets earn a real nonstochastic 5.5 percent rate of return, and that individuals receive actuarially fair annuities beginning at age sixtyfive. There are no bequests in either the preretirement or postretirement years. With these assumptions, the aggregate balance in the PRA accounts reaches 38 percent of gross domestic product (GDP) by the year 2030 and 79 percent of GDP by the year $2070 .{ }^{21}$

The extent to which this accumulation of PRA assets raises the nation's capital stock depends on the way in which other private and public saving responds to the introduction of investment-based Social Security. We ignore these issues here and focus only on the way in which the introduction of bequests would alter the accumulation of PRA assets. ${ }^{22}$

Although our framework of analysis in the current paper does not permit us to calculate the effects of bequests on aggregate PRA assets in each year, we can show the impact of bequests on PRA asset accumulation by comparing the mean PRA asset values for representative individuals of different ages under the different bequest assumptions. The figures in column (1) of table 9.6 are the cohort's aggregate PRA accumulations with no bequests. These figures, based on a saving rate of 6 percent, are in billions of 1998 dollars and are shown as a function of the age of the cohort members. The cohort's PRA assets rise from $\$ 54$ billion at age thirty to $\$ 978$ billion at age sixty before beginning a postretirement decline during the next decade. These aggregate accumulation values correspond to amounts per cohort member of approximately $\$ 16,000$ at age thirty and $\$ 280,000$ at age sixty.

The effect of preretirement bequests is shown in column (2). Each figure in this column shows the assets at the identified age as a percentage of the baseline assets shown in column (1). Most of the reduction in assets occurs at ages close to retirement. At age fifty, the mean PRA balance is 96.7

21. The analysis is partial equilibrium and ignores the effect of this calculation on the marginal product of capital, the level of wages, and the tax rates required to fund government purchases of goods and services. An updated version of this analysis, using Social Security projections of 1998, is presented in Feldstein and Samwick (1999).

22. The effect of bequests on national saving depends also on what the individual bequest recipients do with the received amount. 
PRA Assets as a Percent of the No Bequest Baseline with Different Bequest Rules

\begin{tabular}{lccccc}
\hline Age & $\begin{array}{c}\text { No Bequests } \\
\text { Baseline (\$billion) } \\
(1)\end{array}$ & $\begin{array}{c}\text { Preretirement } \\
\text { Bequests Only } \\
(2)\end{array}$ & $\begin{array}{c}\text { 10-Year } \\
\text { Certain } \\
(3)\end{array}$ & $\begin{array}{c}\text { 20-Year } \\
\text { Certain } \\
(4)\end{array}$ & $\begin{array}{c}\text { Residual } \\
\text { Balance } \\
(5)\end{array}$ \\
\hline 30 & 54 & 99.5 & 99.5 & 99.5 & 99.5 \\
40 & 181 & 98.5 & 98.5 & 98.5 & 98.5 \\
50 & 446 & 96.7 & 96.7 & 96.7 & 96.7 \\
60 & 978 & 92.1 & 92.1 & 92.1 & 92.1 \\
70 & 917 & 86.3 & 87.5 & 92.6 & 91.2 \\
80 & 546 & 86.3 & 80.7 & 106.0 & 106.8 \\
90 & 179 & 86.2 & 80.6 & 71.2 & 116.7 \\
\hline
\end{tabular}

Notes: Baseline PRA Assets are based on a PRA plan with no bequests. Dollar amounts are in 1998 dollars. The other bequest options all assume the preretirement bequests. The postretirement bequests shown in columns (4) through (6) are based on single life annuities.

percent of the no-bequest baseline amount. This declines to 86.6 percent by the time of retirement and remains at that level because no further bequests are made. These figures imply that the net reduction in total PRA assets of all generations at a point in time is likely to be less than 10 percent.

A ten-year certain annuity (in combination with the preretirement bequests), shown in column (3), implies a decline in PRA assets at all ages. Until retirement age, the decline is the same as with the pure preretirement bequest, because the ten-year certain annuity is only available after retirement age. Between ages sixty-seven and seventy-seven the PRA assets decline more slowly because the annuity payout rate is reduced in order to finance the ten-year certain option. The difference, however, is not large. After age seventy-seven the assets are smaller than with only the preretirement bequests because of the larger average annuity payout between ages sixty-seven and seventy-seven and the corresponding reduced annuity to be financed after age seventy-seven.

With the twenty-year certain option, the PRA assets actually rise relative to the baseline amount during the early retirement years, because in those years the reduced level of the annuity outweighs the twenty-year certain payments made to the heirs of those who have died. By age eightyseven, however, the annuity payments must be lower than in the ten-year certain case (to compensate for the greater number of years of guaranteed benefits), and therefore the assets that support those annuities must be lower.

Finally, the residual balance bequests imply higher assets at all ages because of the much more substantial reduction of the annuity payments. Unlike the ten-year certain and twenty-year certain annuities, in the residual balance case the assets do not decline in old age because the annuity 
benefits remain unchanged, and the expected value of the residual balance bequest increases as the assets accumulate.

In general, therefore, permitting bequests is likely to reduce PRA assets by relatively small amounts. Even these modest declines overstate the effect of bequests on total capital accumulation because they do not take into account the effect of bequests on non-PRA assets that are accumulated as a result of PRA bequests. Moreover, if the PRA saving rate is adjusted to stabilize the annuity levels, the net effects of bequests on asset accumulation would be positive.

\subsection{Conclusions}

Experience in private pension plans and recent policy discussions about Social Security suggest that some form of bequests is likely to be part of any enacted investment-based Social Security reform. This paper provides a first examination of the potential magnitudes of such bequests and of their effect on retirement annuities and asset accumulation.

Investment-based PRAs would accumulate substantial funds, some of which would be distributed as bequests. We analyze the effects of a 6 percent saving rate, a level that would provide a nearly 80 percent probability that the annuity payments at age sixty-seven are at least equal to the future benefits promised in current Social Security law. (Pure PAYGO financing would require a payroll tax rate of more than 18 percent to finance the same benefits.) With such a saving rate, the cohort reaching age twentyone in 1998 would expect to accumulate more than $\$ 50$ billion by age thirty and more than $\$ 900$ billion by age sixty, all expressed in the prices of 1998 . These amounts are about $\$ 16,000$ per employee at age thirty and $\$ 300,000$ at age sixty.

The most likely form of bequest is the preretirement bequest, made when employees die before retirement age. The alternative to such bequests would be a 100 percent tax at death on all accumulated PRA assets or an administratively complex system of mandatory annuitization of all savings as they accumulate. Providing such bequests reduces the funds available for postretirement annuities by about 16 percent or, equivalently, requires a one-sixth increase in the PRA saving rate (e.g., from 6 percent to 7 percent) to maintain the same level of postretirement annuities as would be possible with the mandatory annuitization of all savings.

We also analyze a variety of postretirement bequest options. The least costly option that we consider is adding a ten-year certain feature to the life annuity, thereby providing a bequest whenever the retiree dies before age seventy-seven. This would reduce annuities, relative to providing only preretirement bequests, by about 6 percent. The most costly option that we consider would provide a bequest equal to the remaining actuarial value of 
the PRA annuity at the time of death and would require reducing all annuities by about 29 percent. These reductions in the annuity levels could be avoided by increasing the PRA saving rate by a corresponding amount.

The size of the bequests and the impact on asset accumulation are proportional to the PRA saving rate. The results in this paper are based on a PRA saving rate of 6 percent, a level of saving that could in principle eventually substitute completely for the PAYGO tax and finance all benefits with a margin of safety. The PRA saving rate required for the more realistic task of stabilizing the current 12.4 percent payroll tax rate, while maintaining the benefits projected under current law, would be about 2 percent. The pension and capital accumulation effects of such a mixed system would be about one-third of the amounts shown in this paper.

\section{References}

Bernheim, Douglas, and S. Severinov. 1999. Bequests as signals: An explanation for the equal division puzzle, unigeniture, and ricardian non-equivalence. Stanford University, Department of Economics. Mimeograph, April.

Bernheim, Douglas, A. Shleifer, and L. Summers. 1985. The strategic bequest motive. Journal of Political Economy 93 (6): 1045-76.

Brown, Jeffrey R., Olivia S. Mitchell, and James M. Poterba. 1999. The role of real annuities and indexed bonds in an individual accounts retirement program. In Risk aspects of investment-based social security reform, ed. John Campbell and Martin Feldstein, 321-60. Chicago: University of Chicago Press.

Feldstein, Martin, ed. 1998. Privatizing social security. Chicago: University of Chicago Press.

Feldstein, Martin, and E. Ranguelova. 1998. Individual risk and intergenerational risk sharing in an investment based social security system. NBER Working Paper no. 6893. Cambridge, Mass.: National Bureau of Economic Research.

Feldstein, Martin, E. Ranguelova, and A. Samwick. 1999. The transition to investment-based social security when portfolio returns and capital profitability are uncertain. In Risk aspects of investment-based social security reform, ed. John Campbell and Martin Feldstein, 41-81. Chicago: University of Chicago Press.

Feldstein, Martin, and A. Samwick. 1997. The economics of prefunding Social Security and Medicare benefits. In NBER macroeconomics annual 1997, 115-47. Cambridge, Mass.: MIT Press.

. 1998a. Potential effects of two percent personal retirement accounts. Tax Notes 79 (5): 615-20.

. 1998b. The transition path in privatizing social security. In Privatizing Social Security, ed. M. Feldstein, 215-60. Chicago: University of Chicago Press.

. 1999. Maintaining Social Security benefits and tax rates through personal retirement accounts: An update based on the 1998 Social Security Trustees Report. NBER Working Paper no. 6540R. Cambridge, Mass.: National Bureau of Economic Research, March.

Kotlikoff, Laurence. 1996. Privatization of social security: How it works and why it matters. Tax Policy and the Economy 10:1-32. 
- 1998. Simulating the privatization of social security in general equilibrium. In Privatizing Social Security, ed. M. Feldstein, 265-310. Chicago: University of Chicago Press.

Rosen, Harvey, D. Holtz-Eakin, and D. Joulfaian. 1993. The Carnegie conjecture: Some empirical evidence. Quarterly Journal of Economics 108 (May): 413-35. World Bank. 1994. Averting the old age crisis. Washington, D.C.: World Bank.

\section{Comment Jonathan Skinner}

One positive influence of a privatized Social Security system is that contributors feel a proprietary interest in their accumulating accounts. This encourages greater responsibility for prudent investment choices and helps contributors to view Social Security payments as saving rather than a burdensome tax. Developing a proprietary interest, however, also raises the potential for resentment in the event of an early death - why, the contributor might think, should the government confiscate my investments? Under the current system, of course, there is little or no sense of ownership, so the idea that benefits cease at the time of death does not appear quite so unfair.

Feldstein and Ranguelova have anticipated this hurdle faced by a privatized Social Security system and have proposed a sensible and economically sound solution - that contributors be allowed to bequeath some of their accumulated benefits in the event of an early death. The purpose of the paper is to quantify how much a modest bequest package would cost, either in terms of increased payments into the Social Security system or in terms of reduced benefits. The major result is that the costs of setting up such a program are quite modest, often costing less than 1 percentage point of additional saving. The analysis is very carefully performed, and I have no reservations about the approach that they take or the parameter values they use to estimate the costs of bequests.

What I will argue in these comments is that Feldstein and Ranguelova are, if anything, too modest in presenting their case for bequests, or for some kind of lump-sum award near death. The potential tradeoff between annuities and a payoff near death holds for any Social Security system. That is, enrollees in the current Social Security system may be willing to give up modest levels of benefits, or pay slightly more in taxes or contributions, so as to enjoy the insurance value of lump-sum payments in the event of early death or other contingency. Indeed, there is a death benefit equal to $\$ 255$ under the current Social Security system, apparently de-

Jonathan Skinner is the John French Professor of Economics at Dartmouth College and a research associate of the National Bureau of Economic Research. 
signed to help with burial costs, but clearly not indexed to inflation! Although the Feldstein and Ranguelova results are clearly designed to dovetail with a more thoroughly developed Social Security plan (as in Feldstein and Samwick 1997; Feldstein, Ranguelova, and Samwick 2001; or Kotlikoff 1996), the striking results shown in their paper raise a more general issue about the optimal payout schedule for any annuitization program.

It is useful as a starting point to think about a simple life-cycle model wherein the only uncertainty is the time of death. Then the individual would prefer to annuitize all retirement wealth, and the optimal Social Security benefit should replicate the optimal postretirement consumption stream. If the optimal consumption path increases over time (for example, because the interest rate exceeds both the discount rate and the annual probability of dying), then the Social Security payment should increase over time, and conversely. In this idealized story, Social Security provides complete annuitization of retirement consumption, and it is smooth, without death benefits or any contingency payment. Even in the case in which Social Security provides incomplete annuitization, as is true for the vast majority of Social Security beneficiaries, the optimal Social Security payment could be a smooth consumption payment that might even increase over time in real terms to provide the maximum degree of insurance against living to an old age.

As Feldstein and Ranguelova and others have observed, the world is not simply a certainty life-cycle model. People do have preferences to leave bequests, whether through life insurance policies at younger years, or by choosing "ten-year certain annuities at retirement (through TIAACREF), which pay ten years of benefits, either to the primary enrollee or to the designated heir, following an early death.

It is useful to distinguish, as Feldstein and Ranguelova do, between bequests designed for younger decedents and bequests for older postretirement decedents. For younger contributors, grafting an actuarially fair term life insurance with low administrative costs onto a privatized Social Security system is not very expensive as long as the probability of death is low. The benefits could also be substantial, particularly if the decedent has not adequately provided for his or her spouse and children; Bernheim et al. (1999), for example, suggest that many households hold life insurance coverage that would prove inadequate should the principal earner die.

It is important to note that Social Security already has in place survivorship benefits that partially address this problem for younger decedents. In 1996 , an average of $\$ 487$ per month was paid to some 1.9 million dependent children of deceased enrollees, for a total of about $\$ 11$ billion annually (U.S. House of Representatives 1998). Paying out an annuity may be more useful for supporting children, since a single lump-sum life insurance payment could be spent rapidly by a surviving parent or stepparent, leav- 
ing little or nothing for the child's support. On the other hand, their proposed insurance plan does not replace the dependent children program, but supplements it; the revenue projections in the Feldstein, Ranguelova, and Samwick (2001) proposal allow for full continued funding of the program for dependent children and spouses.

The issues surrounding bequests among postretirement elderly people are somewhat more complicated, as the cost of such a program can be quite large, given the much higher mortality rates in this population and hence the much higher costs of providing a death benefit. ${ }^{1}$ Nor is there quite the same perceived need for bequests beyond spousal support, since the children of the decedents are typically either at their peak earning capacity or nearly retired themselves. Nevertheless, Feldstein and Ranguelova have touched upon a legitimate desire for retirees to leave bequests, and as long as they are willing to pay more in taxes, or reduce their annuitized benefits, it is reasonable to consider providing such an option.

Evidence from the 1995 Survey of Consumer Finances certainly appears to support the view that the demand for leaving a bequest is strong. Of a broad sample of individuals asked, more than half replied that they thought leaving a bequest is important or very important (Dynan, Skinner, and Zeldes 2000). If anything, the fraction desiring to leave a bequest was slightly higher among high school dropouts than among college graduates, so the interest exists across broad socioeconomic groups. Thus, it might appear that providing an option to leave a bequest provides exactly what contributors want. ${ }^{2}$

A somewhat different view, however, on the motives for saving comes from respondents to a question in the 1983-1989 Survey of Consumer Finances panel with respect to their motives for saving. Of retired households, 43 percent replied either "in case of illness" or "emergencies" as their most important reasons for saving, with less than 5 percent mentioning saving for their children. How can these two survey responses be reconciled? Dynan, Skinner, and Zeldes (2000) suggest a model in which saving while old serves a dual role of both guarding against future catastrophic or end-of-life expenses (with a small probability $p$ ) and the more likely function of providing a bequest for heirs (with a higher probability of $1-p$ ).

The message from these survey questions, therefore, suggests a more complicated story than a simple bequest motive. If a Social Security sys-

1. It seems likely, however, that mortality for this age group will fall in coming years (Lee and Skinner 1999), making the bequest option that much less costly.

2. This raises a related question: Why don't enrollees simply save for a bequest on their own? The answer may be linked to the justification for a forced saving program such as Social Security; perhaps there is a problem with making intertemporal plans that are dynamically consistent among some households, as in Laibson (1997) or Akerlof (1991). 
tem wanted to replicate, through forced saving, what people said they were saving for, then the nature of the benefits might be quite different from a bequest. Perhaps beneficiaries would prefer an option that allows them to spend down some of their bequest balances for nursing home care or medication should they be stricken with serious illness. Perhaps a program that protects them against inflationary erosion of bonds or other assets that they rely upon for retirement income would be another option. An elderly couple in which one person is battling Alzheimer's disease may prefer to access some of their cash balances instead of passing them along to their heirs.

Instituting such a program would raise all sorts of difficult questions in terms of who is and is not eligible to access the bequest balances and how to design the program to prevent abuses or fraud. Particularly for a privatized Social Security system with personal accounts, a simple bequest program might be most practical, particularly if private markets arise that allow beneficiaries to borrow against such payments. However, the general point remains that if the Social Security system, privatized or not, wishes to expand benefits beyond the standard option that provides for a smooth level of annuity payments, it should determine why people save, and design benefits that capture, as closely as possible, those motives for saving.

\section{References}

Akerlof, George A. 1991. Procrastination and obedience. American Economic Review 81 (2): 1-19.

Bernheim, B. Douglas, Lorenzo Forni, Jagadeesh Gokhale, and Laurence J. Kotlikoff. 1999. The adequacy of life insurance: Evidence from the health and retirement survey. NBER Working Paper no. 7372. Cambridge, Mass.: National Bureau of Economic Research, October.

Dynan, Karen, Jonathan Skinner, and Stephen Zeldes. 2000. Do the rich save more? Dartmouth College. Mimeograph.

Feldstein, Martin, Elaine Ranguelova, and Andrew Samwick. 2001. The transition to investment-based social security when portfolio returns and capital productivity are uncertain. In Risk aspects of investment based social security reform, ed. J. Campbell and Martin Feldstein, 41-87. Chicago: University of Chicago Press.

Feldstein, Martin, and Andrew Samwick. 1997. The economics of prefunding social security and Medicare benefits. NBER Macroeconomics Annual 1997. Cambridge, Mass.: MIT Press.

Kotlikoff, Laurence. 1996. Rescuing Social Security. Challenge 39 (6): 21-22.

Laibson, David. 1997. Golden eggs and hyperbolic discounting. Quarterly Journal of Economics (May): 443-77.

Lee, Ron, and Jonathan Skinner. 1999. Will aging baby boomers bust the federal budget? Journal of Economic Perspectives 13 (1): 117-40.

U.S. House of Representatives. Committee on Ways and Means. 1998. 1998 green book overview of entitlements programs. Washington, D.C.: GPO. 


\section{Discussion Summary}

Stephen C. Goss noted that, although Social Security does not provide a lump-sum bequest, it does provide child survivor benefits as well as benefits for a spouse caring for a child. The present value of these benefits to a twenty-seven-year-old with average earnings, a spouse, and two young children is between $\$ 250,000$ and $\$ 300,000$. These benefits are intended to replace lost income. If the twenty-seven-year-old had life insurance or other assets, these monthly Social Security survivor benefits would allow a family to maintain its existing assets. In this situation there is little difference between a lump sum benefit and an annuity.

Gary Burtless believed that there is not a very strong public policy case for bequests. Why should a labor tax be imposed on everybody to fund bequests? Why should old age and survivor benefits be linked to bequests to people that may not have any financial need for these bequests? Clearly, this is a very inefficient way to reduce the Gini coefficient for the financial wealth distribution. The authors responded that there are two reasons to study bequests. First, people seem to like bequests, because they do not want the wealth in their government-sponsored individual accounts to be taken away by the government when they die. Perhaps more importantly, there has been significant interest in bequests by the policy makers considering Social Security reform, so whether or not bequests are a good idea, it is important to understand how they would work. In particular, a senator may believe that increasing the individual account contribution rate from 6 percent to 7 percent is a reasonable price to pay for having a system with bequests, and providing policy makers with the information necessary to make those choices is valuable.

Stephen Zeldes worried about the availability of annuities in private markets. If the level of annuitization is reduced in the current system or a system with individual accounts, will people be able to purchase similar annuities from financial institutions? Is there a large adverse selection problem in the private sector? Mandatory annuities in the Social Security system may be actuarially more fair than annuities offered by insurance companies.

Jeffrey B. Brown found the residual balance annuity to be a somewhat puzzling design feature. If a retiree's estate receives the full remaining actuarial balance of the account after death, then the retiree's resources are no longer really annuitized. Instead, the retiree is simply amortizing the account balance at a variable rate over the maximum remaining life span. One implication of this amortization approach is that the choice of the maximum life span has a more important effect on the income that is available to retirees than true life annuities, the future payments of which are discounted by survival probabilities. In this paper, the account balance is amortized over thirty-three years, which may not be long enough, given 
that more and more people are living beyond age 100. A higher maximum life span would further reduce the income that is available from these residual balance annuities.

Eytan Sheshinski indicated that first-best efficiency could be achieved using life insurance markets. After retirement, when most of the uncertainty about income has unfolded, individuals want a bequest of a particular size. A ten-year certain (any year certain) annuity merely offers a random bequest, because the size of the bequest depends upon when the individual dies. Bundling Social Security and bequests seems to have problems. Why not allow people to choose the size of their bequest by purchasing life insurance with some percentage of their Social Security benefits? In addition, it could be interesting to examine simulations in which bequests before retirement are an increasing function of age. Such a program would definitely be more cost-effective and might be sensible if bequests become more important as people age.

Laurence J. Kotlikoff mentioned a reason to avoid committing to life insurance. Because income uncertainty is largely unresolved for a retired individual's children, the size of the bequest motive could be changing significantly over time. Since life insurance and annuity markets have adverse selection problems and administrative costs, many people might decide to share risk with their children and avoid the private sector completely.

Martin Feldstein emphasized a more basic problem that underlies all discussions of bequests. The standard models indicate that people will choose to buy some combination of life insurance and annuities. Clearly, the decision-making procedure is poorly understood because the actual behavior observed is quite different. People care about leaving something to the next generation, but they also care about how they make this bequest. For example, people might desire to bequeath wealth in the same way that it was bequeathed to them. The recent stock market rise has made universities, museums, and so on very rich, yet that has not stopped donors from contributing after these organizations met their goals for capital accumulation. People care about the process. 
